Mobile learning technology readiness and acceptance among pre-service teachers in Pakistan during the COVID19 pandemic

Muhammad Zaheer Asghar

Elena Barberà

Universitat Oberta de Catalunya, Barcelona, Spain

Iram Younas

University of Management and Technology, Lahore, Pakistan

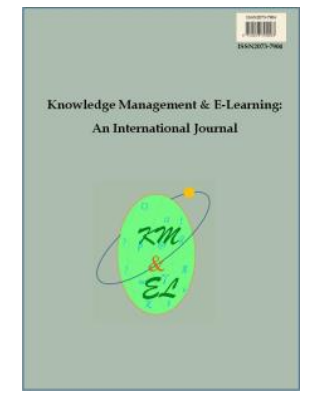

Knowledge Management \& E-Learning: An International Journal (KM\&EL) ISSN 2073-7904

Recommended citation:

Asghar, M. Z., Barberà, E., \& Younas, I. (2021). Mobile learning technology readiness and acceptance among pre-service teachers in Pakistan during the COVID-19 pandemic. Knowledge Management \& ELearning, 13(1), 83-101. https://doi.org/10.34105/j.kmel.2021.13.005 


\title{
Mobile learning technology readiness and acceptance among pre-service teachers in Pakistan during the COVID- 19 pandemic
}

\author{
Muhammad Zaheer Asghar* \\ School of Doctorate, ICT \& Education (e-learning) \\ Universitat Oberta de Catalunya, Barcelona, Spain \\ E-mail: chancellor.zaheer@gmail.com or masghar@uoc.edu
}

\section{Elena Barberà}

Psychology and Education Sciences

Universitat Oberta de Catalunya, Barcelona, Spain

E-mail: ebarbera@uoc.edu

\section{Iram Younas}

Department of Education

University of Management and Technology, Lahore, Pakistan

E-mail: iramyounas1234@gmail.com

*Corresponding author

\begin{abstract}
Accessibility in education during the COVID-19 pandemic is a big challenge around the world. This study aimed to investigate pre-service teachers' accessibility, acceptability, and readiness with respect to mobile learning (M-learning) technology and the relationships between M-learning acceptance and readiness. The questionnaires adopted the Unified Theory of Acceptance and Use of Technology. The survey was conducted with 429 preservice teachers from public and private universities in Pakistan. It was found that mobile phones and the Internet are easily accessible to pre-service teachers. The results reveal that personal innovation, quality of services, and social influence have a significant direct impact on behavioral intention to use $\mathrm{M}$ learning technology. Personal innovation and quality of services have an indirect effect on M-learning readiness. On the contrary, the study found a direct effect of effort expectancy, performance expectancy, personal innovation, quality of services, and behavioral intentions on M-learning readiness. The implications of the findings are also discussed.
\end{abstract}

Keywords: COVID-19 pandemic; Mobile learning; Pre-service teachers; Teacher education; Technology acceptance

Biographical notes: Dr. Muhammad Zaheer Asghar is a researcher in the area of Information and Communication Technologies \& Education (e-learning) at Universitat Oberta de Catalunya, Barcelona, Spain. http://transfer.rdi.uoc.edu/en/researcher/asghar-muhammad-zaheer

Dr. Elena Barberà is a full professor and Director of the Education and ICT $\mathrm{Ph}$.D. program at Universitat Oberta de Catalunya, Barcelona, Spain. Her area 
of interest is educational psychology, e-learning, and teacher education. More details can be found at https://www.uoc.edu/webs/ebarbera/EN/curriculum/index.html

Iram Younas is a post-graduate student at the Department of Education, University of Management and Technology, Lahore, Pakistan. Her area of interest is mobile phone technology learning and pre-service teacher education.

\section{Background}

Due to the COVID-19 pandemic, thousands of educational institutions have been closed to promote social distancing measures and thus limit the virus spread (Naciri, Baba, Achbani, \& Kharbach, 2020; Sintema, 2020). This critical situation highlights several concerns, such as the decline in the quality of education and students' learning outcomes (Naciri et al., 2020; Usak, Masalimova, Cherdymova, \& Shaidullina, 2020). It is a matter of paramount concern to implement innovative pedagogical methods and curriculum practices to strengthen the teaching-learning process in schools, colleges, and universities (Naciri et al., 2020; Toquero, 2020).

Several studies have investigated mobile learning (M-learning) to explain the use of mobile devices in educational contexts (Naciri et al., 2020; Sönmez, Göçmez, Uygun, Ataizi, \& Learning, 2018). M-learning can be referred to the educational process that involves learning through mobile phones (Naciri et al., 2020; Chang \& Hwang, 2018; Crompton \& Burke, 2018). M-learning combines different information and communication technologies that provide education anytime and anywhere (UNESCO, 2016). Kim, Rueckert, Kim, and Seo (2013) claimed that teachers are motivated to include technology in curriculum and instructions for the sake of students' better learning. Some researchers have found that the use of modern technologies may increase students' self-efficacy for learning (Jan, Ullah, Ali, \& Khan, 2016). Other relevant advantages of M-learning are that mobile devices provide learning opportunities outside the classroom and M-learning develops higher-order thinking skills among students (Naqvi, 2019). According to Wang and Ryu (2009), students can develop an interest in learning and improve their weak areas through the use of the mobile phone. Students can discuss their learning problems with their friends and teachers out of the class through mobile phones. Teachers can use WhatsApp and other social media platforms to share course materials and announcements. Generally, M-learning benefits students in developing technological and conversational experiences, finding solutions to their problems, promoting a spirit of collaboration, supporting information sharing, and leveraging their educational outcomes (Al-Emran, Elsherif, \& Shaalan, 2016).

In Pakistan, the number of mobile phone users has increased rapidly from 5.02 million to 164 million (77.69\% teledensity) during the last few years (Pakistan Telecommunication Authority, 2020). Almost $77 \%$ of the population of Pakistan owns a mobile phone. There are 75 million ( $35 \%$ penetration) broadband subscribers and 74 million (35.21\% penetration) 3G and 4G subscribers in Pakistan (PTA, 2020). Mobile devices like smartphones and tablets have become an essential part of the daily life of young people. According to the Annual Status of Education Report (ASER, 2019), 68\% of the people living in remote or rural areas own mobile phones. $44 \%$ of mobile users make use of the WhatsApp application for communication, while $67 \%$ of mobile users depend on SMS communication in Pakistan's rural areas (ASER, 2019). 
Educational institutions in Pakistan are mostly situated in urban areas. Some students travel long distances for the learning purpose and reside in hostels. Socially and economically marginalized children, persons with disabilities, and female students face accessibility issues in education in Pakistani society. According to the Pakistan Bureau of Statistics (PBS, 2019), the country's total literacy rate was $62.3 \%$ in 2017-18 (for males, it was $72.5 \%$, and for females, it was $51.8 \%$ ). Area wise analysis reports that the literacy rate in rural areas was $53.3 \%$ (for males it was $66 \%$ and for females, it was $40 \%$ ), while the urban area's literacy rate was $76.6 \%$ (for males it was $82 \%$ and for females, it was $70 \%$ ). The disparity was observed between urban and rural areas' literacy rates as well as male and female literacy rates.

UNESCO and Nokia have collaborated to launch an application to educate people in rural areas where most people are unable to get access to education. UNESCO aimed to increase the literacy rate through a project named "Pakistan e-Taleem," which delivered material through DVDs, arranged assessment in open learning centers, and provided training in rural areas. There are many other ongoing projects to facilitate learning through the use of mobile phone technology. Currently, learners show a positive attitude towards the use of the mobile phone for educational and social activities (Gikas \& Grant, 2013). Most teachers also found that iPads and applications are attractive for teaching (Wang \& Chang, 2012). However, the success of learning depends on many other factors (Arif, Asghar, \& Mukhtar, 2020).

However, M-learning is not something that automatically happens with the availability of mobile phones. Currently, there is little research available to determine the factors that affect pre-service teachers' readiness for M-learning (Cheon et al., 2012). Traxler (2007) suggested finding the degree of readiness for M-learning for graduate and postgraduate students rather than K-12 students because graduate and postgraduate students own mobile phones. Wang, Wu, and Wang (2009) claimed that despite the benefits of M-learning, there are some challenges regarding its adoption, such as software and hardware issues that may affect M-learning's readiness. Teachers are an essential stakeholder in implementing M-learning. However, there is less research available about the acceptance of M-learning among teachers in Pakistan. The available research is mostly about e-learning among higher education students (Qureshi, Ilyas, Yasmin, \& Whitty, 2012). It is essential to focus on pre-service teachers due to their role in higher education and as future practitioners in K-12 schools. M-learning is also an emerging trend that is in the early stages of development in higher education and teacher education institutions (Park, 2011). More research is required to assess the challenges of readiness for M-learning (Hussin, Manap, Amir, \& Krish, 2012). Besides M-learning readiness, Mlearning acceptance is also significant for pre-service teachers. Significantly, the pandemic has also increased the importance of the readiness and acceptance of m-leaning, which is required to maintain social distancing without affecting the teaching-learning process. It needs to produce teachers to implement M-learning in the field, which is impossible without implementing M-learning first in teacher education institutions.

There are four hundred and seven accredited teacher education programs in Pakistan (NACTE, 2020). Only one available teacher education department in Pakistan offers a postgraduate program in ICT education. Two universities offer virtual and distance learning programs. Distance and virtual universities generally kept working during the pandemic. Simultaneously, the teaching-learning process at traditional teacher education institutions suffered due to the sudden shift in the learning approach. Researchers have studied different aspects of ICT and learning for pre-service teachers in Pakistan. Majoka, Fazal, and Khan (2013) studied the implementation of ICT courses in teacher education programs. Abdullah and Mirza (2020) evaluated the teaching practice 
for distance and online teacher education institutions. Soomro, Kale, and Yousuf Zai (2014) studied the pre-service teachers' attitude towards learning through social networks in Pakistan. Nevertheless, sufficient research is not available about how to utilize ICT, especially widely available mobile phones in an emergency. Teacher education policymakers could not prepare a proper strategy to adopt mobile learning approaches during the pandemic.

\section{Objectives of the study}

Successful M-learning adoption during a pandemic depends on whether pre-service teachers are ready to accept the new technology, which is different from the traditional technologies and fulfills their learning needs (Mac Callum \& Jeffrey, 2013) during the pandemic. This study aimed to investigate the pre-service teachers' level of acceptance and readiness for M-learning in Pakistan during the pandemic. It focused on addressing the following research questions.

RQ1: Are mobile phones and the Internet accessible to pre-service teachers?

RQ2: What's the level of acceptance and readiness for M-learning among pre-service teachers?

RQ3: What is the relationship between M-learning acceptance and M-learning readiness among pre-service teachers?

Further, RQ3 involves the following hypotheses.

H1: There is a correlation between readiness and the factors of acceptance for Mlearning among pre-service teachers

H2: There is a direct effect of the factors of M-learning acceptance on pre-service teachers' readiness for mobile learning

H3: There is a meditating role of the pre-service teachers' intentions towards $M$ learning between the antecedents of M-learning (performance expectancy, effort expectancy, personal innovativeness, quality service, and social influence) and $M$ learning readiness

\section{Theoretical foundation}

\subsection{Mobile learning readiness and acceptance}

Corbeil and Valdes-Corbeil (2007) and Keller (2011) stated that the study of M-learning readiness is an essential factor prior to the adoption of M-learning. M-learning readiness is the ability of a learning organization to benefit from mobile phone resources (Lopes et al., 2007). Borotis and Poulymenakou (2004) elaborated on M-learning readiness as the learners' preparedness to benefit from the use of the mobile phone in the learning process. This study has adopted two questionnaires to measure mobile learning readiness (MLR) and mobile learning acceptance (MLA).

This study has adopted the mobile learning readiness questionnaire from Hussin et al. (2012). The MLR questionnaire was comprised of 12 questions. The MLR aimed to collect information about the pre-service teachers' M-learning readiness in terms of Mlearning meaning and their perceived attitude towards M-learning. The questions 
concentrated on essential readiness, skills readiness, psychological readiness, and budget readiness. Previous studies have used MLR questionnaires as a single construct (Mahat, Ayub, \& Luan, 2012). Therefore, this study also did not breakdown the MLR questionnaire into subfactors.

The second instrument was adopted from the mobile learning acceptance (MLA) questionnaire used by Jairak, Praneetpolgrang, and Mekhabunchakij (2009) to measure the pre-service teacher's mobile learning acceptance. The MLA questionnaire was based on the survey instruments developed by Venkatesh et al. (2003) and Wang et al. (2009). The MLA questionnaire's factors are based on the Unified Theory of Acceptance and Use of Technology (UTAUT) used in different studies (Anderson \& Schwager, 2004; Sidik \& Syafar 2020). MLA factors are performance expectancy, social influence, service quality, effort expectancy, and behavioral intentions (Venkatesh et al., 2003; Wang et al., 2009). Jairak et al. (2009) found the MLA a reliable instrument with Cronbach's alpha ranged from .8 to .9 , a more satisfactory reliability level.

Research in technology acceptance has resulted in different models for the explanation of individual intentions and behaviors regarding the use of innovative technology. These models are based on the theories of information systems, psychology, and sociology (e.g., Davis, Bagozzi, \& Warshaw, 1989; Taylor \& Todd, 1995; Venkatesh \& Davis, 2000; Venkatesh et al., 2003). This research is based on the Unified Theory of Acceptance and Use of Technology (UTAUT). Technological acceptance models produced by researchers include Theory of Reasoned Action (TRA) (Fishbein \& Ajzen, 1976), Technology Acceptance Model (TAM) (Davis et al., 1989), Theory of Planned Behaviour (TPB) (Ajzen, 1991), and Model of Personal Computer Utilization (MPCU) (Thompson, Higgins, \& Howell, 1991).

\subsection{Unified theory of acceptance and use of technology (UTAUT)}

UTAUT is a useful alternative model in information technology (Venkatesh et al., 2003). It is a successful model that assesses the acceptance of innovative technology. The UTAUT model investigates the acceptance of learning mainly through covariates, such as age and gender differences play an essential role in M-learning acceptance. Together TAM and TPB theories, IS theories, and social psychology theories gave rise to UTAUT and its factors of performance expectancy, effort expectancy, social influence, facilitation, personal innovation, behavioral intention, and the use of technology (Venkatesh et al. 2003).

Performance Expectancy (PE) is defined by Venkatesh et al. (2003) as the extent to which a person believes that his or her performance would increase by the use of technology. PE influences behavioral intention. It improves the students' learning output (Wang et al., 2009). The use of mobile positively or negatively affects the students' performance. Bad and good results can be measured through the PE factor. The gender and age of the users also affect the PE factor.

Effort Expectancy (EE) is defined by Venkatesh et al. (2003) as the ease of way to use. Effort expectancy relates to the previous study's ease to use in TAM and complexity in MPCU. Ease to use is an essential factor in technology.

Social Influence (SI) is the factor that makes a person believe that the use of new technology increases their connectivity with other people (Venkatesh et al., 2003). This factor presented as the subjective norms in the TRA, TAM2, TPB, and C-TAM-TPB, 
social factors in MPCU. Superior influence and peer influence constitute the dimensions of SI (Igbaria, Schiffman, \& Wieckowski, 1994).

Quality of Service (QS); This factor is the term consistency and response, quality of the content, and security. The definition of this factor is the perceptions of the customers about quality of facilities or product. Facilitating conditions in mobile learning technology are students' expectation about the service of the mobile.

According to Ajzen (1991), Behavioral Intentions (BI) are determined to perform a specific act. In this research, behavioral intentions are meant to pre-service teachers' mindset for mobile learning. Certain factors affect intentions, such as social influence (Asghar et al., 2019).

\section{Method}

The quantitative cross-sectional survey method was used to collect data from public and private universities. A questionnaire was adapted based on previous studies. Factors of UTAUT were measured through a Likert-type scale. The current study's population included all the departments of education in higher education institutions $(n=26)$ located in Pakistan. A random sampling technique was used to select the departments of education from private sector universities $(n=2)$ and public sector universities $(n=2)$. A survey was conducted with pre-service teachers $(n=429)$ enrolled in undergraduate and postgraduate programs in the education departments of Pakistani universities. The sample distribution is shown below in Table 1 .

Table 1

Demographics of the survey respondents

\begin{tabular}{cccc}
\hline & & frequency & $\%$ \\
\hline \multirow{2}{*}{ Gender } & Male & 136 & 31.7 \\
& Female & 292 & 68.1 \\
& $<20$ & 102 & 23.8 \\
& $20-25$ & 284 & 66.2 \\
& $26-30$ & 26 & 6.1 \\
& $31-35$ & 8 & 1.9 \\
\multirow{2}{*}{ Program } & $>36$ & 9 & 2.1 \\
& Bachelor & 238 & 55.5 \\
& Masters & 87 & 20.3 \\
& MPhil & 91 & 21.2 \\
& PhD & 12 & 2.8 \\
\hline
\end{tabular}

The first part of the questionnaire comprises demographics such as gender, age, and experience. The second part of the questionnaire is about the accessibility of the Internet and mobile phone. The third part of the questionnaire comprises the M-learning readiness of the pre-service teachers in terms of its definition, attitude towards Mlearning, and perceptions for M-learning. It contains twelve items on a Likert-type scale ranging from 1 (strongly disagree) to 5 (strongly agree). The fourth part comprises Mlearning technology acceptance. It has 23 items on a Likert-type scale $(1=$ strongly 
disagree to $5=$ strongly agree) distributed in five subfactors: 4 items for performance expectancy, four items for effort expectancy, four items for personal innovativeness, three items for social influence, four items for service quality, and four items for behavioral intentions.

Data were entered into SPSS software. Data cleaning was performed to find out the missing values. Data were assessed for outliers, normality, skewness, and kurtosis. Confirmatory Factor Analysis (CFA) was performed to confirm the factors. The reliability of the questionnaire was observed as satisfactory $(\alpha>.800)$. Descriptive statistics were applied to measure the mean and standard deviation of the factors. The correlation test was applied to measure the inter variable correlation for further analysis. Path analysis was performed to measure the mediation of the factors between independent and dependent variables.

\section{Results}

Data were screened to find out the missing values and outliers. Normality, skewness, and kurtosis of the data were found to be appropriate $(-1.96>x<1.96)$. The reliability of the instrument and its factors was $>0.8$. CFA was performed to observe the construct validation. The factor loading of the items was $>0.7$. The AVE of each factor was greater than .5 , and the $\mathrm{CR}$ value for each factor was greater than .8 , with $\mathrm{KMO}=.82$ at significance level $p<.001$.

\subsection{Descriptive statistics}

It was found that pre-service teachers have access to smartphones $(f=358,83.4 \%)$ and the Internet $(f=335,78.1 \%)$. They $(f=342,79.7 \%)$ use the Internet every day-they $(f=$ $342,79.7 \%$ ) use educational applications on their mobile devices. Descriptive statistics about the availability of mobile phones and the Internet are given in Table 2.

All the M-learning acceptance factors, overall M-learning acceptance, and Mlearning readiness showed the tendency towards agreeableness on a Likert-type scale that ranged from $1=$ strongly disagree to $5=$ storngly agree. Table 3 represents the descriptive statistics of factors.

\subsection{Inferential statistics}

A correlation test was run to measure the inter variable correlation among the factors to assess the following hypothesis:

H1: There is a correlation between readiness and the factors of acceptance for $M$ learning among pre-service teachers

According to the results, performance expectancy $(\mathrm{M}=3.77, \mathrm{SD}=.91)$ has a significant positive correlation with effort expectancy $(r=.64, p<.01)$, social influence $(r=.546, p<.01)$, quality of services $(r=.552, p<.01)$, personal innovativeness $(r$ $=.457, p<.01)$, behavioural intentions $(r=.425, p<.01)$ and M-learning readiness $(r$ $=.551, p<.01)$.

Effort expectancy $(\mathrm{M}=3.73, \mathrm{SD}=.88)$ has a significant positive correlation with social influence $(r=.573, p<.01)$, quality of services $(r=.577, p<.01)$, personal 
innovativeness $(r=.502, p<.01)$, behavioural intentions $(r=.461, p<.01)$ and $\mathrm{M}$ learning readiness $(r=.593, p<.01)$.

Table 2

Descriptive statistics of respondents' mobile phone and Internet accessibility

\begin{tabular}{|c|c|c|}
\hline Aspects & frequency & $\%$ \\
\hline \multicolumn{3}{|l|}{ Mobile devices } \\
\hline Nokia 3310 & 33 & 7.7 \\
\hline smartphone & 358 & 83.4 \\
\hline tablet PC & 10 & 2.3 \\
\hline other devices & 28 & 6.5 \\
\hline \multicolumn{3}{|c|}{ Accessibility on the Internet } \\
\hline Yes & 335 & 78.1 \\
\hline No & 94 & 21.9 \\
\hline \multicolumn{3}{|l|}{ Internet use } \\
\hline Everyday & 342 & 79.7 \\
\hline Once a week & 35 & 8.2 \\
\hline Monthly & 25 & 5.8 \\
\hline Rarely & 27 & 6.3 \\
\hline \multicolumn{3}{|c|}{ Campus Wireless Network } \\
\hline Yes & 181 & 42.2 \\
\hline No & 247 & 57.6 \\
\hline \multicolumn{3}{|c|}{ Access to the Internet outside the campus } \\
\hline Yes & 324 & 75.5 \\
\hline No & 105 & 24.5 \\
\hline \multicolumn{3}{|c|}{ Payment required for Internet access } \\
\hline Yes & 339 & 79.0 \\
\hline No & 88 & 20.5 \\
\hline \multicolumn{3}{|c|}{ Price of Internet access via your mobile device } \\
\hline High Price & 151 & 35.2 \\
\hline Normal Price & 227 & 52.9 \\
\hline Low Price & 50 & 11.7 \\
\hline \multicolumn{3}{|c|}{ Use of educational applications } \\
\hline Yes & 342 & 79.7 \\
\hline No & 84 & 19.6 \\
\hline \multicolumn{3}{|c|}{ heard about mobile learning } \\
\hline Yes & 266 & 62.0 \\
\hline No & 160 & 37.3 \\
\hline
\end{tabular}

Social influence $(\mathrm{M}=.37, \mathrm{SD}=.87)$ has a significant positive correlation with the quality of services $(r=.577, p<.01)$, personal innovativeness $(r=.543, p<.01)$, behavioral intentions $(r=.542, p<.01)$ and M-learning readiness $(r=.585, p<.01)$. 
Quality of services $(\mathrm{M}=3.81, \mathrm{SD}=.79)$ has a significant positive correlation with personal innovativeness $(r=.583, p<.01)$, behavioral intentions $(r=.601, p<.01)$, and M-learning readiness $(r=.702, p<.01)$.

Personal innovativeness $(\mathrm{M}=3.75, \mathrm{SD}=.79)$ has a significant positive correlation with behavioral intentions $(r=.486, p<.01)$ and M-learning readiness $(r$ $=.608, p<.01)$.

Behavioural intentions $(\mathrm{M}=3.62, \mathrm{SD}=.82)$ have a significant positive correlation with M-learning readiness $(r=.692, p<.01)$.

Table 3

Descriptive statistics of the factors

\begin{tabular}{llllll}
\hline & N & Min & Max & Mean & SD \\
\hline PE & 429 & 1 & 5 & 3.778 & 0.911 \\
EE & 429 & 1 & 5 & 3.736 & 0.882 \\
SI & 429 & 1 & 5 & 3.705 & 0.875 \\
QS & 429 & 1 & 5 & 3.816 & 0.798 \\
PI & 429 & 1 & 5 & 3.758 & 0.795 \\
BI & 429 & 1 & 5 & 3.625 & 0.827 \\
MLR & 429 & 1 & 5 & 3.844 & 0.753 \\
MLA & 429 & 1 & 5 & 3.736 & 0.665 \\
\hline
\end{tabular}

Note. PE = Performance Expectancy; EE = Effort Expectancy; SI = Social Influence; QS = Quality of Services; PI = Personal Inventiveness; BI = Behavioral Intentions; MLR = Mobile Learning Readiness; MLA = Mobile Learning Acceptance.

\subsection{Path analysis}

Path analysis was applied to find out the relationship between variables. Performance expectancy, effort expectancy, personal innovation, and quality of services are exogenous variables, behavioral intentions constitute the mediating variable, and mobile phone readiness is the endogenous variable. The model of mobile phone readiness is given below in Fig. 1.

Multivariate analysis was run. Minimum of good fit was achieved with (Chisquare $=23.747, \mathrm{DF}=20$ and $\mathrm{P}=.254$ ). The parameters of the model fit were also found to be a good fit (RMR <.05, RMSEA <.05, CFI, GFI, AGFI, and PGFI > .90).

The second hypothesis assessed the direct effects of the factors as follows:

H2: There is a direct effect of the factors of M-learning acceptance on pre-service teachers' readiness for mobile learning

Gender $(\beta=-.01, p>.05)$ and program $(\beta=-.01, p>.05)$ have no direct effect on behavioral intentions and M-learning readiness. Personal innovation $(\beta=.12, \mathrm{SE}=.05, p$ $<.01)$, quality of services $(\beta=.37, \mathrm{SE}=.06, p<.01)$, and social influence $(\beta=.22, \mathrm{SE}=$ $.06, p<.01)$ have a significant direct effect on behavioral intentions. Effort expectancy $(\beta$ $=.11, \mathrm{SE}=.06, p<.01)$, performance expectancy $(\beta=.07, \mathrm{SE}=.03, p<.05)$, and behavioral intentions $(\beta=.31, \mathrm{SE}=.04, p<.01)$ have a direct effect on M-learning readiness. 


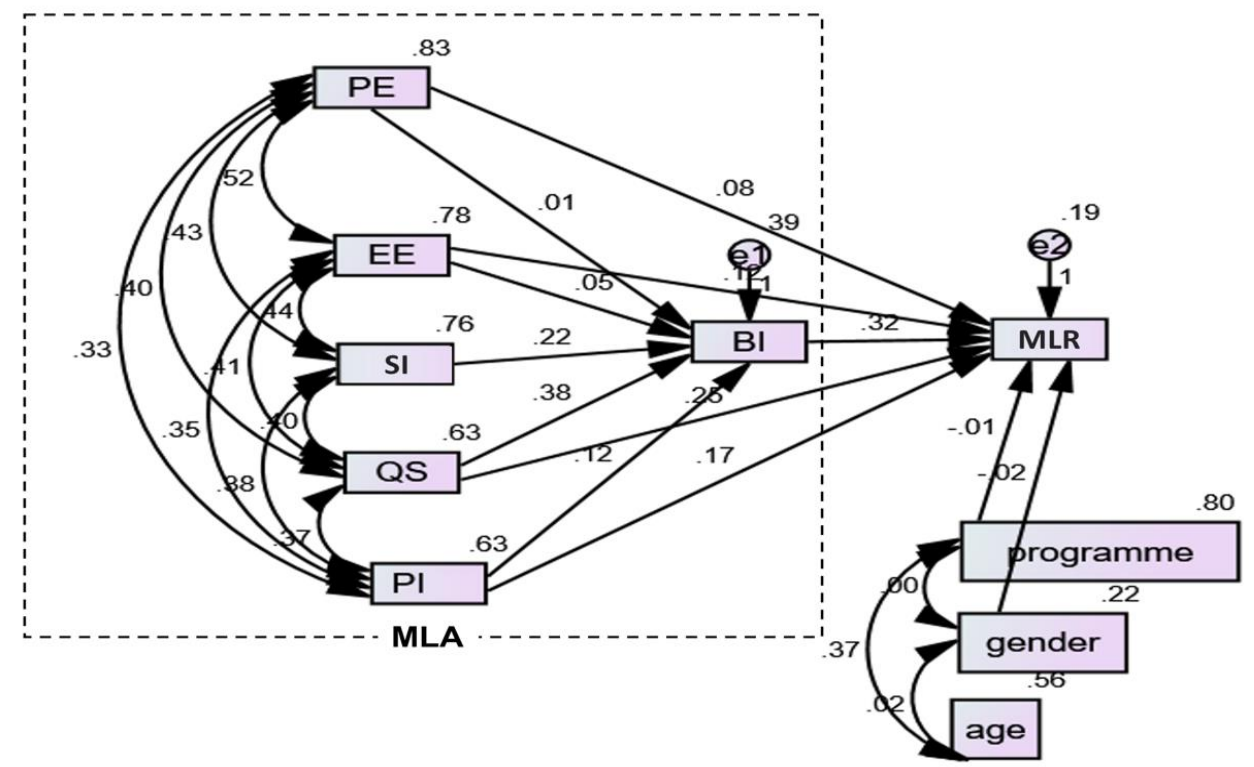

Fig. 1. Mobile phone learning readiness among pre-service teachers

The third hypothesis assessed the indirect effects as follows:

H3: There is a meditating role of pre-service teachers' intentions towards M-learning between antecedents of M-learning (performance expectancy, effort expectancy, personal innovativeness, quality of services, and social influence) and M-learning readiness

Personal innovation $(\beta=.03, \mathrm{SE}=.019, p<.01)$, quality of services $(\beta=.11, \mathrm{SE}$ $=.02, p<.001)$, and social influence $(\beta=.07, \mathrm{SE}=.023, p<.01)$ have a positive and significant indirect effect on M-learning readiness through the mediating factor of behavioral intentions.

\section{Discussion}

RQ1: Are mobile phones and the Internet accessible to pre-service teachers?

M-learning has numerous benefits and advantages. Firstly, this pedagogical aspect can transpire anytime, anywhere, and the educational process is not restricted to a specific place (Corbeil \& Valdes-Corbeil, 2007). Additionally, it allows educators to personalize guidance (Steel, 2012) and enable learners to self-regulate their education (Sha, Looi, Chen, \& Zhang, 2012). It is essential for students to have access to the internet and mobile phone to benefit from M-learning.

It was found that some pre-service teachers used Nokia 3310 type (non-android) mobile phone that is a hurdle in accessing the information available online. Mostly, preservice teachers use androids and tablet pcs for their teaching and learning. These devices enhance the possibility of M-learning. Students have access to free internet inside the university premises, while they need to purchase the internet outside the university. Preservice teachers use educational applications, and they are aware of M-learning. Very few students do not have access to the internet outside the university. Some students spend a 
high amount on the internet, while others spend a low amount of time. The internet is an essential factor in online learning. Most of the teachers use the internet for science teaching and language teaching and engage the students for learning (Almaiah \& Alismaiel, 2019; Chen \& Chen 2008; Postholm, 2010). Hussin et al. (2012) stated that Mlearning depends on two types of readiness: basic readiness and budget readiness. Park (2011) stated that infrastructure readiness was the basic requirement of pre-service teachers' M-learning readiness. The type of mobile also plays an essential role in Mlearning readiness and acceptance. Crompton \& Burke (2018) describe that mobile phones with a small memory size and low battery capacity make students unhappy and deter them from M-learning.

RQ2: What's the level of acceptance and readiness for M-learning among pre-service teachers?

The factors of performance expectancy, effort expectancy, social influence, quality of services, personal innovativeness, behavioral intentions, M-learning readiness, and overall M-learning acceptance showed the pre-service teachers' tendency towards an agreement that reflects acceptance and readiness of pre-service teachers for M-learning. The same results were found by a study conducted in Turkey (Çakıroğlu, Gökoğlu, \& Öztürk 2017; Çubukçu, Tosuntaş, \& Kircaburun, 2017). M-learning is a sort of e-learning, an innovative way to gain knowledge. A high score on the agreeableness of performance expectancy and effort expectancy for M-learning among pre-service teachers ratified the results that M-learning facilitates the students and develops the interaction between the learner and the teacher (Alioon \& Delialioğlu, 2019; Khaddage, Lanham, \& Zhou, 2009). M-learning supports students in the continuous learning process. Students can gain knowledge anytime, anywhere (Georgieva, Smrikarov, \& Georgiev, 2005; Qiu, 2019). It can be defined as the connection between the technologies of mobile and web learning (Alioon \& Delialioğlu, 2019; Fu, 2018; Khaddage et al., 2009; Qiu, 2019).

Pre-service teachers demonstrated that M-learning could help the students access the learning materials on their mobile devices and tablet. Mobile technology has become a concrete solution for students' educational problems (Grant, 2019; Kommers \& Hooreman, 2009). It is said that $70 \%$ of people watch YouTube on their mobile devices. YouTube gets almost 500 million views daily related to learning. Shelley Osborne (major publisher of MOOCs and education developer of Udemy) observed that 24 million people get content material through mobile. The research findings can also be applicable at the school level, where these pre-service teachers will be serving as practitioners. According to Domingo and Garganté (2016), learners are eager to participate when they learn through mobile. It provides support to students and allows them to develop new and selfdirected goals in their education at every level.

RQ3: What is the relationship between M-learning acceptance and M-learning readiness among pre-service teachers?

UTAUT model was used in this research by adding the different extended factors such as M-learning readiness, personal innovativeness, and quality of services. This study showed a significant positive correlation among all the factors of UTAUT, such as performance expectancy, effort expectancy, social influence, quality of services, personal innovativeness, behavioral intentions, and M-learning readiness. The same results were obtained by researchers (Aliaño, Hueros, Franco, \& Aguaded, 2019; Chong, Chan, \& Ooi, 2012; Wang et al., 2009) that students' readiness was associated with the factors of UTAUT. 
Performance expectancy. The results showed no direct effect of performance expectancy on the pre-service teachers' intentions to accept M-learning and indirectly on M-learning readiness. It aligns with the previous studies, which mentioned that performance expectancy does not influence mobile learning readiness and acceptance (Kwan, Hermawan, \& Hafizhi, 2019; Moreno \& Molina, 2012). Performance expectancy directly influenced the M-learning readiness of pre-service teachers, which aligns with the findings of most of the previous studies about performance expectancy (Liu, Li, \& Carlsson, 2010; McGill \& Klobas, 2009; Venkatesh et al., 2003). M-learning provides complimentary help to the traditional lecture method. Students who believed that mobile phones are helpful in their studies were ready to accept the technology, rather than those students who had lower performance expectations (Liu et al., 2010).

Effort Expectancy. The current study showed that effort expectancy has no direct and indirect effect on pre-service teachers' M-learning acceptance and readiness, respectively. These findings align with the findings of some previous studies (Assegaff, 2016; Sedana \& Wijaya, 2010; Thomas \& Nurkhin, 2016). According to Assegaff, Kurniabudi, and Hendri (2016) and Sikumbang (2014), there is no impact of effort expectancy on behavioral intentions. Effort expectancy has a direct influence on the Mlearning readiness of pre-service teachers. The results of this research align with the original study of Venkatesh et al. (2003). Effort expectancy significantly influences the behavior of the students (Chong et al., 2012; Wang et al., 2009). M-learning is a method that is easy to use, and it saves time, provides convenient access, and makes lectures exciting. Technology helps students to collaborate, and collaborative learning approaches are essential for the learning process (Viilo, Seitamaa-Hakkarainen, \& Hakkarainen, 2011) that develops students' mind to use mobile phones for learning.

Social Influence. The results of the social influence factor are in accordance with the results of social influence presented by Venkatesh et al. (2003), who defines social influence as the extent to which an individual acknowledges that other people have an important role to play in the system. The results of this study showed a significant positive correlation of social influence with participant's intention for online learning (Agustin \& Mulyani, 2016; Muhsin \& Nurkhin, 2016; Nasir, 2013; Sedana \& Wijaya, 2010). Social influence showed a significant impact on the behavior of students through the use of M-learning. Moreover, the perception of teachers regarding the acceptance of mobile technology motivates them to implement it.

Quality of Services. The quality of services of infrastructure and M-learning facilities such as the internet, hardware, and software impact readiness both directly and indirectly. It also impacts directly M-learning acceptance among pre-service teachers. Persada, Miraja, and Nadlifatin (2019) and Zhou, Lu, and Wang (2010) and other studies also depict the same results. The institutions need to provide students with reliable and useful learning materials to improve the quality of services.

Personal Innovativeness. Students' willingness and adoption of the new technology include personal innovativeness factors. This study showed that personal innovativeness has a direct effect on M-learning intentions and an indirect effect on Mlearning acceptance. Zarmpou, Saprikis, Markos, and Vlachopoulou (2012) also revealed that personal innovativeness has a significant impact on the intentions to adopt $\mathrm{M}$ learning. An instructional strategy must be designed to enhance the innovativeness of the students regarding how to use technology (Tan, Ooi, Leong, \& Lin, 2014; Liu et al., 2010). 
Intentions towards M-learning. The intention to use mobile for learning has a direct effect on the M-learning readiness of pre-service teachers. The previous studies (Fauz, Widodo, \& Djatmiko, 2018) also depict the same results.

Demographic factors. Previous studies (Aliaño et al., 2019; Georgieva et al., 2005; Jacob \& Issac, 2008; Trifonova, Georgieva, \& Ronchetti, 2006) postulated that gender and experience have a direct influence on students' intentions to use mobile phone for learning. Gender and experience showed no direct impact on mobile usage readiness of the students, which is unlike the results of previous studies (Georgieva et al., 2005; Ning, Yang, Zhu, Bayarmaa, \& Ma 2019; Trifonova et al., 2006; Jacob \& Issac, 2008). It might be due to the effect of the pandemic that both female and male students were forced to stay at home, and they did not have any alternative other than to accept Mlearning as the only available option.

\section{Conclusion}

For the continuation of teaching to students in the circumstances of confinement induced by the novel coronavirus, M-learning is an essential educational technology in higher education. It makes it feasible for learners to learn, collaborate, and share ideas. The current research concluded that pre-service teachers are ready to accept mobile phone technology for the teaching-learning process in education. The reason behind the acceptance of mobile phone technology for learning is that mobile phones and internet services are available everywhere in Pakistan. Universities are facilitating preservice teachers by providing free of cost internet services. University teachers also encourage pre-service teachers towards M-learning. Pre-service teachers understand that the mobile phone is easy to use for learning. They also perceive that the mobile phone helps them to enhance their learning experiences. They know the innovative ways of mobile phone usage for learning. This research showed the pre-service teachers' intentions towards Mlearning and their readiness towards the use of M-learning technologies. Mobile phones and internet services are available in remote areas of Pakistan. Therefore, it is concluded that the readiness of pre-service teachers would also help to reduce accessibility issues in the field of education in remote and rural areas of Pakistan.

\section{Implications of the findings}

The findings are useful for the educators and administrators of teacher education institutes and they vouch for the promotion of M-learning. This research will be helpful for teacher education institutions to develop infrastructure, policy, instructional strategies, and designs to enhance M-learning acceptance among pre-service teachers. It provides an insight for the educational professionals in higher educational institutes about how Mlearning can be utilized in our education system. The outcomes will be helpful for curriculum and instructional designers to design instructions for better learning of the students.

It is recommended here that more technical infrastructure must be provided in the universities to facilitate M-learning. Seminars and workshops must be organized to train the teachers for M-learning. This step will be useful in the learning process of pre-service teachers. Training courses must be introduced for the development of pre-service teachers related to M-learning. 
Regarding the accessibility of the internet and mobile phone, Pakistan Telecommunication Authority (PTA) should develop student packages to facilitate poor students. Teacher education institutions may produce agreements with mobile phone companies to sell mobiles free of interest and on easy installments. Poor students need to be provided with mobile phones free of cost during the pandemic to continue their education without any restriction. Universities should provide access to cloud services to the students.

The educational institutions' immediate shift to e-learning during the pandemic was experimental and faced many issues. The outcomes of the exceptional experience of M-learning during the pandemic can be used in the future. The lessons acquired from the COVID-19 will cause the emergence of new regulations, directions, policies, and resolutions for future events (Basilaia \& Kvavadze, 2020; Naciri et al., 2020). This research invites more future studies to provide solutions for different challenges that affect M-learning.

\section{Limitations of the study}

Two questionnaires were used in this study to collect the data. However, a mixedmethods approach might be utilized for an in-depth inquiry. The cross-sectional survey only explained the phenomenon at a specific point in time. The methodology may be extended to incorporate longitudinal research elaborating more profound results for postpandemic implications. However, this study has the potential to generalize its findings for pre-service teachers to higher education students from other disciplines.

\section{Author Statement}

The authors declare that they have no conflict of interest.

\section{ORCID}

Muhammad Zaheer Asghar (iD https://orcid.org/0000-0003-2634-0583

Elena Barberà (D) https://orcid.org/0000-0002-9315-8231

Iram Younas (iD https://orcid.org/0000-0002-5747-8158

\section{References}

Abdullah, N. A., \& Mirza, M. S. (2020). Evaluating pre-service teaching practice for online and distance education students in pakistan: Evaluation of teaching practice. The International Review of Research in Open and Distributed Learning, 21(2), 8197.

Agustin, H., \& Mulyani, E. (2016). Studi empiris penerimaan dan penggunaan e-learning system di kalangan mahasiswa akuntansi fakultas ekonomi unp. Seminar Nasional Aplikasi Teknologi Informasi, 12, e17- e22.

Ajzen, I. (1991). The theory of planned behavior. Organizational Behavior and Human Decision Processes, 50(2), 179-211.

Al-Emran, M., Elsherif, H. M., \& Shaalan, K. (2016). Investigating attitudes towards the use of mobile learning in higher education. Computers in Human Behavior, 56, 93- 
102.

Aliaño, A. M., Hueros, A. D., Franco, M. G., \& Aguaded, I. (2019). Mobile learning in university contexts based on the unified theory of acceptance and use of technology (UTAUT). Journal of New Approaches in Educational Research, 8(1), 7-17.

Alioon, Y., \& Delialioğlu, Ö. (2019). The effect of authentic m-learning activities on student engagement and motivation. British Journal of Educational Technology, 50(2), 655-668.

Almaiah, M. A., \& Alismaiel, O. A. (2019). Examination of factors influencing the use of mobile learning system: An empirical study. Education and Information Technologies, 24(1), 885-909.

Anderson, J. E., \& Schwager, P. H. (2004, February). SME adoption of wireless LAN technology: Applying the UTAUT model. In Proceedings of the 7th Annual Conference of the Southern Association for Information Systems (Vol. 7, pp. 39-43).

Annual Status of Education Report (ASER). (2019). Scope \& scale. Retrieved from http://aserpakistan.org/document/report_cards/2018/summary_report_cards/National_ 2018.pdf

Arif, S., Asghar, Z., \& Mukhtar, S. (2020). Interactive effect of school principals' leadership styles and teacher characteristics on curriculum implementation at public secondary schools of Punjab. UMT Education Review, 3(1), 95-119.

Asghar, M. Z., Gul, F., Seitamaa-Hakkarainen, P., \& Tasdemir, M. Z. (2019). Validating entrepreneurial intentions questionnaire to assess the impact of entrepreneurship education. Eğitim ve bilim, 44(197), 383-399.

Assegaff, S. (2016). Analisis perilaku penerimaan EDMODO pada perkuliahan dengan model UTAUT. Jurnal Nasional Teknologi dan Sistem Informasi, 2(3), 1-10.

Assegaff, S., Kurniabudi, K., \& Hendri, H. (2016). Social media success for knowledge sharing: Instrument content validation. International Journal of Electrical and Computer Engineering, 6(5), 2447-2453.

Basilaia, G., \& Kvavadze, D. (2020). Transition to online education in schools during a sars-cov-2 coronavirus (covid-19) pandemic in Georgia. Pedagogical Research, 5(4): em0060.

Borotis, S., \& Poulymenakou, A. (2004). E-learning readiness components: Key issues to consider before adopting e-learning interventions. In Proceedings of the E-Learn: World Conference on E-Learning in Corporate, Government, Healthcare, and Higher Education (pp. 1622-1629). Association for the Advancement of Computing in Education (AACE).

Çakıroğlu, Ü., Gökoğlu, S., \& Öztürk, M. (2017). Pre-service computer teachers' tendencies towards the use of mobile technologies: A technology acceptance model perspective. European Journal of Open, Distance and E-learning, 20(1), 175-190.

Chang, C. Y., \& Hwang, G. J. (2018). Trends in smartphone-supported medical education: A review of journal publications from 2007 to 2016. Knowledge Management \& ELearning, 10(4), 389-407.

Chen, J., \& Chen, Z. (2008). Extended bayesian information criteria for model selection with large model spaces. Biometrika, 95(3), 759-771.

Cheon, J., Lee, S., Crooks, S. M., \& Song, J. (2012). An investigation of mobile learning readiness in higher education based on the theory of planned behavior. Computers \& Education, 59(3), 1054-1064.

Chong, A. Y. L., Chan, F. T. S., \& Ooi, K. B. (2012). Predicting consumer decisions to adopt mobile commerce: Cross country empirical examination between China and Malaysia. Decision Support Systems, 53(1), 34-43.

Corbeil, J. R., \& Valdes-Corbeil, M. E. (2007). Are you ready for mobile learning? Educause Quarterly, 30(2), 51-58. 
Crompton, H., \& Burke, D. (2018). The use of mobile learning in higher education: A systematic review. Computers \& Education, 123, 53-64.

Çubukçu, Z., Tosuntaş, Ş. B., \& Kircaburun, K. (2017). Investigation of pre-service teachers'opinions toward mobile technologies within the frame of technology acceptance model. Asian Journal of Instruction, 5(2), 1-18.

Davis, F. D., Bagozzi, R. P., \& Warshaw, P. R. (1989). User acceptance of computer technology: A comparison of two theoretical models. Management Science, 35(8), 982-1003.

Domingo, M. G., \& Garganté, A. B. (2016). Exploring the use of educational technology in primary education: Teachers' perception of mobile technology learning impacts and applications' use in the classroom. Computers in Human Behavior, 56, 21-28.

Fauz, A., Widodo, T., \& Djatmiko, T. (2018). Pengaruh behavioral intention terhadap use behavior pada penggunaan aplikasi transportasi online (studi Kasus Pada Pengguna Go-jek Dan Grab Di Kalangan Mahasiswa Telkom University). eProceedings of Management, 5(2). 1790-1796.

Fishbein, M., \& Ajzen, I. (1976). Misconceptions about the Fishbein model: Reflections on a study by Songer-Nocks. Journal of Experimental Social Psychology, 12(6), 579584.

$\mathrm{Fu}, \mathrm{Q}$. K. (2018). Impacts of mobile technologies, systems and resources on language learning: A systematic review of selected journal publications from 2007-2016. Knowledge Management \& E-Learning, 10(4), 375-388.

Georgieva, E., Smrikarov, A., \& Georgiev, T. (2005, June). A general classification of mobile learning systems. In Proceedings of the International Conference on Computer Systems and Technologies - CompSysTech.

Gikas, J., \& Grant, M. M. (2013). Mobile computing devices in higher education: Student perspectives on learning with cellphones, smartphones \& social media. The Internet and Higher Education, 19, 18-26.

Grant, M. M. (2019). Difficulties in defining mobile learning: Analysis, design characteristics, and implications. Educational Technology Research and Development, 67(2), 361-388.

Hussin, S., Manap, M. R., Amir, Z., \& Krish, P. (2012). Mobile learning readiness among Malaysian students at higher learning institutes. Asian Social Science, 8(12), 276-283.

Igbaria, M., Schiffman, S. J., \& Wieckowski, T. J. (1994). The respective roles of perceived usefulness and perceived fun in the acceptance of microcomputer technology. Behaviour \& Information Technology, 13(6), 349-361.

Jacob, S. M., \& Issac, B. (2008). Mobile technologies and its impact-an analysis in higher education context. International Journal of Interactive Mobile Technologies, 2(1), $10-18$.

Jairak, R., Praneetpolgrang, P., \& Mekhabunchakij, K. (2009, December). An investigation of trust in e-learning for instructors and students in private and public universities. In Proceedings of The Sixth International Conference on eLearning for Knowledge-Based Society.

Jan, R., Ullah, F., Ali, H., \& Khan, F. (2016). Enhanced and practical learning through mobile learning insight into students' perception of mobile learning at University Level. International Journal of Scientific Research in Science, Engineering, and Technology, 2(2), 674-681.

Keller, R. (2011). Diskursforschung. Wiesbaden: VS Verlag für Sozialwissenschaften.

Khaddage, F., Lanham, E., \& Zhou, W. (2009). A mobile learning model for universitiesre-blending the current learning environment. International Journal of Interactive Mobile Technologies, 3(S1), 18-23.

Kim, D., Rueckert, D., Kim, D. J., \& Seo, D. (2013). Students' perceptions and experiences of mobile learning. Language Learning \& Technology, 17(3), 52-73. 
Kommers, P. A. M., \& Hooreman, R. W. (2009). Mobile phones for real-time teacher coaching. Journal of Research in Innovative Teaching, 2(1), 80-90.

Kwan, F. P., Hermawan, L. R., \& Hafizhi, N. (2019). E-hrm: Pain or gain for hrm effectiveness. Jurnal TAM, 10(1), 22-32.

Liu, Y., Li, H., \& Carlsson, C. (2010). Factors driving the adoption of m-learning: An empirical study. Computers \& Education, 55(3), 1211-1219.

Lopes, S. L. B., dos Santos, J. S., \& Scarpelini, S. (2007). The implementation of the medical regulation office and mobile emergency attendance system and its impact on the gravity profile of non-traumatic afflictions treated in a university hospital: A research study. BMC Health Services Research, 7: 173.

Mac Callum, K., \& Jeffrey, L. (2013). The influence of students' ICT skills and their adoption of mobile learning. Australasian Journal of Educational Technology, 29(3). 303-314.

Mahat, J., Ayub, A. F. M., \& Luan, S. (2012). An assessment of students' mobile selfefficacy, readiness and personal innovativeness towards mobile learning in higher education in Malaysia. Procedia-Social and Behavioral Sciences, 64, 284-290.

Majoka, M. I., Fazal, S., \& Khan, M. S. (2013). Implementation of information and communication technologies (ICTs) in education course: A case from teacher education institutions in Pakistan. Bulletin of Education and Research, 35(2), 37-53.

McGill, T. J., \& Klobas, J. E. (2009). A task-technology fit view of learning management system impact. Computers \& Education, 52(2), 496-508.

Moreno, R. R., \& Molina, C. M. (2012, July). Social network sites and e-learning adoption. In Proceedings of the International conference on ICT in teaching and learning (pp. 69-79). Springer.

Muhsin, T. P., \& Nurkhin, A. (2016). Intention to use e-journal: A unified theory of acceptance and use of technology perspective. IOSR Journal of Research \& Method in Education, 6(4), 100-106.

Naciri, A., Baba, M. A., Achbani, A., \& Kharbach, A. (2020). Mobile learning in higher education: Unavoidable alternative during covid-19. Aquademia, 4(1): ep20016.

Naqvi, T. Z. (2019). Diastolic function assessment incorporating new techniques in Doppler echocardiography. Reviews in Cardiovascular Medicine, 4(2), 81-99.

Nasir, M. (2013, June). Evaluasi penerimaan teknologi informasi mahasiswa di Palembang menggunakan model UTAUT. Seminar Nasional Aplikasi Teknologi Informasi (SNATI).

National Accreditation Council for Teacher Education (NACTE). (2020). List of accerdiated programmes. Retrieved from http://www.nacte.org.pk

Ning, F., Yang, Y., Zhu, T., Bayarmaa, T. I., \& Ma, N. (2019). Influence of pre-service and in-service teachers' gender and experience on the acceptance of AR technology. In Proceedings of the International Conference on Smart Learning Environments (pp. 125-134). Springer.

Pakistan Bureau of Statistics (PBS). (2019). Labour force survey. Retrieved from https://www.pbos.gov.pk/content/pakistan-statistical-year-book-2018-provisional

Pakistan Telecommunication Authority (PTA). (2020). Telecom indicators. Retrieved from https://www.pta.gov.pk/en/telecom-indicators

Park, Y. (2011). A pedagogical framework for mobile learning: Categorizing educational applications of mobile technologies into four types. International Review of Research in Open and Distributed Learning, 12(2), 78-102.

Persada, S. F., Miraja, B. A., \& Nadlifatin, R. (2019). Understanding the generation Z behavior on d-learning: A unified theory of acceptance and use of technology (UTAUT) approach. International Journal of Emerging Technologies in Learning, 14(5), 20-33. 
Postholm, M. B. (2010). Self-regulated pupils in teaching: Teachers' experiences. Teachers and Teaching: Theory and Practice, 16(4), 491-505.

Qiu, W. (2019). U.S. Patent No. 10,321,722. Washington, DC: U.S. Patent and Trademark Office.

Qureshi, I. A., Ilyas, K., Yasmin, R., \& Whitty, M. (2012). Challenges of implementing e-learning in a Pakistani university. Knowledge Management \& E-Learning, 4(3), $310-324$

Sedana, I. G. N., \& Wijaya, S. W. (2010). UTAUT model for understanding learning management system. Internetworking Indonesia Journal, 2(2), 27-32.

Sha, L., Looi, C. K., Chen, W., \& Zhang, B. (2012). Understanding mobile learning from the perspective of self-regulated learning. Journal of Computer Assisted Learning, 28(4), 366-378.

Sidik, D., \& Syafar, F. (2020). Exploring the factors influencing student's intention to use mobile learning in Indonesia higher education. Education and Information Technologies, 25(6), 4781-4796.

Sikumbang, E. D. (2014). Penerapan model utaut dalam sistem pembelajaran e-learning. Paradigma-Jurnal Komputer dan Informatika, 16(1), 84-92.

Sintema, E. J. (2020). Effect of covid-19 on the performance of grade 12 students: Implications for stem education. Eurasia Journal of Mathematics, Science and Technology Education, 16(7): em1851.

Sönmez, A., Göçmez, L., Uygun, D., \& Ataizi, M. (2018). A review of current studies of mobile learning. Journal of Educational Technology and Online Learning, 1(1), 1227.

Soomro, K. A., Kale, U., \& Yousuf Zai, S. (2014). Pre-service teachers' and teachereducators' experiences and attitudes toward using social networking sites for collaborative learning. Educational Media International, 51(4), 278-294.

Steel, C. (2012). Fitting learning into life: Language students' perspectives on benefits of using mobile apps. In Proceedings of the Ascilite Conference: Future challenges, sustainable future.

Tan, G. W. H., Ooi, K. B., Leong, L. Y., \& Lin, B. (2014). Predicting the drivers of behavioral intention to use mobile learning: A hybrid SEM-Neural Networks approach. Computers in Human Behavior, 36, 198-213.

Taylor, S., \& Todd, P. (1995). Assessing IT usage: The role of prior experience. MIS Quarterly, 19(4), 561-570.

Thomas, P., \& Nurkhin, A. (2016). The development of learning sets and research methodology module using problem based learning for accounting education students. Journal of Accounting and Business Education, 1(1), 77-97.

Thompson, R. L., Higgins, C. A., \& Howell, J. M. (1991). Personal computing: Toward a conceptual model of utilization. MIS Quarterly, 15(1), 125-143.

Toquero, C. M. (2020). Challenges and opportunities for higher education amid the covid-19 pandemic: The philippine context. Pedagogical Research, 5(4): em0063.

Traxler, J. (2007). Defining, discussing and evaluating mobile learning: The moving finger writes and having writ... The International Review of Research in Open and Distributed Learning, 8(2): 3.

Trifonova, A., Georgieva, E., \& Ronchetti, M. (2006, November). Determining students' readiness for mobile learning. In Proceedings of the 5th WSEAS International Conference on E-ACTIVITIES. Venice, Italy.

UNESCO. (2016). Teacher's guide on the prevention of violent extremism. Paris: UNESCO. Retrieved from https://www.casede.org/BibliotecaCasede/NovedadesPDF/UNESCO_Guia_educacion_contra_extremismo_violento.pdf

Usak, M., Masalimova, A. R., Cherdymova, E. I., \& Shaidullina, A. R. (2020). New playmaker in science education: COVID- 19. Journal of Baltic Science Education, 
19(2), 180-185.

Venkatesh, V., \& Davis, F. D. (2000). A theoretical extension of the technology acceptance model: Four longitudinal field studies. Management Science, 46(2), 186204.

Venkatesh, V., Morris, M. G., Davis, G. B., \& Davis, F. D. (2003). User acceptance of information technology: Toward a unified view. MIS Quarterly, 27(3), 425-478.

Viilo, M., Seitamaa-Hakkarainen, P., \& Hakkarainen, K. (2011). Supporting the technology-enhanced collaborative inquiry and design project: A teacher's reflections on practices. Teachers and Teaching: Theory and Practice, 17(1), 51-72.

Wang, M., \& Chang, C. C. (2012). Editorial: Technology in higher education and human performance. Knowledge Management \& E-Learning, 4(3), 231-235.

Wang, P., \& Ryu, H. (2009). Not SMS, but mobile quizzes: Designing a mobile learning application for university students. International Journal of Mobile Learning and Organisation, 3(4),351-365. doi: 10.1504/IJMLO.2009.027453

Wang, Y. S., Wu, M. C., \&Wang, H. Y. (2009). Investigating the determinants and age and gender differences in the acceptance of mobile learning. British Journal of Educational Technology, 40(1), 92-118.

Zarmpou, T., Saprikis, V., Markos, A., \& Vlachopoulou, M. (2012). Modeling users' acceptance of mobile services. Electronic Commerce Research, 12(2), 225-248.

Zhou, T., Lu, Y., \& Wang, B. (2010). Integrating TTF and UTAUT to explain mobile banking user adoption. Computers in Human Behavior, 26(4), 760-767. 